\title{
TOWARDS A TYPOLOGY OF PARALLELISM IN ESTONIAN POETIC FOLKLORE
}

\author{
Mari Sarv
}

\begin{abstract}
The article gives an overview of the uses and features of parallelism across different genres of Estonian poetic folklore, focusing on the genres in which grammatical parallelism forms an important means for structuring texts. Relying on her own previous research on runosongs and short forms of folklore (Sarv 1999, 2000, 2003), the results of the syntactic analysis of runosong texts in Helle Metslang's dissertation (1978), Juhan Peegel's definition of poetical synonyms in runosongs (Peegel 2004), and proceeding from the concept of poetical system (Sarv 2000), the author proposes a definition of the type of parallelism canonical in the Finnic runosong tradition. Two other types of parallelism, used in different genres of Estonian poetic folklore, are discerned on a similar basis, taking into account the relations between the elements of the poetical system. The proposed typology proceeds from the assumption that the regular use (or absence) of euphonic means is related to the type of parallelism used. In this case - as the study proves - the types of parallelism are distinguished by the semantic relations between the parallel elements (words or phrases) in grammatically parallel units, rather than by semantic relations between the whole parallel units or by formal features like range or length. There appears to be a clear tendency: the use of euphony (alliteration and word-structure repetitions) in parallelism types increases in relation to the diminishing of the semantic load of the parallel elements.
\end{abstract}

Keywords: folklore, folk songs, oral poetry, parallelism, poetics, proverbs, riddles, runosong, sayings

\section{INTRODUCTION}

Parallelism is a very general principle governing the creation and essence of poetic texts, and is present in poetic traditions worldwide. There are numerous forms of parallelism in different poetic traditions, some of them regular, some of them with strict regularities, some of them more casual and looser in form. Parallelism in its various forms reveals itself in different genres of Estonian poetic folklore, fitting with the communicative functions specific to each genre.

My investigation into the typology of parallelism arose from the need to define the essence of Estonian runosong tradition, a branch of common Finnic poetic tradition, for the research purposes as well as for the organization and 
systematization of archival collections (i.e. making collections available and accessible for other researchers, as well as for the public). ${ }^{1}$ My studies on runosong parallelism (Sarv 1999, 2000, 2001, 2002, 2015) have led me to the conclusion that, in addition to the formal description of the parallel units, specific semantic relations of the constituents of these parallel units are crucial to characterizing the main form of runosong parallelism. My further studies on the structural preconditions for the euphony in short forms of folklore (Sarv 2003) have allowed me to discern two more types of parallelism on a similar basis.

The typology presented in this article proceeds from the concept of poetical system (Sarv 2000), and the idea that the elements of a poetical system have stable mutual relations forming a coherent whole. Mainly, the argumentation relies on the assumption that parallelism, depending on its semantic nature, may support or hinder the use of euphony. The article aims to detect and characterize 'natural' classes of parallelism present in Estonian poetic folklore, i.e. types of parallelism that can be distinguished by their role in poetical systems.

\section{PARALLELISM AND THE POETIC FUNCTION OF LANGUAGE}

Parallelism as one of the main constituents of the poetic structure of runosongs was described under the name "repetition of thought" (repetitio sententiarum) already by Henrik Gabriel Porthan in his dissertation De Poesi Fennica (Porthan 1766-1788: 17-24; 1983). Porthan also refers to Joh. des Champs who has been using the term "rhyme of thought" (rime du sens) as opposed to "rhyme of sound" (rime du son), to denote similar "harmony of the thoughts and images" in old Hebrew poetry. ${ }^{2}$ The notion 'parallelism' in the meaning of a poetic device was supposedly taken into use in 1788 by Robert Lowth, who with the phrase parallelismus membrorum denoted syntactic and semantic correspondences in contiguous lines of Hebrew sacred poetry (see Küper 1988: 50-51; Fox 2014: 20-22). As the subtypes of parallelism, he distinguished synonymous, antithetic, and synthetic parallelism (the last one denoting the kind of grammatical parallelism in which the semantic relations are not unambiguous).

Gerard Manley Hopkins, an English poet, considered parallelism as a more general phenomenon - as a general poetic principle. The idea was developed further by Roman Jakobson, according to whom parallelism denotes the expression of the poetic function of language with recurrences in any level of language (see, e.g., PT: 42-43; Jakobson \& Pomorska 1983: 102-103). Undoubtedly, parallelism as a poetic device most notably occurs in the grammatically and semantically parallel contiguous units of metric texts, and this is how it is understood in its narrower sense. Parallelism in a broader sense also extends 
to larger units, prose texts, or to smaller units, word pairs, and can be revealed on compositional, grammatical or phonological level (see, e.g., Jakobson 1987: 145-179; Jakobson \& Pomorska 1983: 106-107; O’Connor 1993).

Parallelism is very common in the folklore of various nations, in all probability it has had its specific tasks and functions in the conditions of orality, helping to memorize stories and thoughts, to secure the message to be understood, to emphasize the importance of a message, to create the poetic text ad hoc in a relevant situation, etc. (on the use of parallelism in folklore see, e.g., Fox 2014). Parallelism can be used as an optional ornament in a text or as a common and canonical compositional device that is unavoidable in the texts belonging to the poetic tradition, genre or subgenre of folklore, and forms an essential part of the poetic system of this genre. Parallelism is of course not all the same in different poetic traditions or genres. In order to describe a specific form of parallelism, and to compare it to the other forms of parallelism, we need some kind of classification or typology based on the characteristic features distinguishing the types of parallelism.

According to Roman Jakobson's definition, the poetic function - expressed by parallelism in a broader sense - projects the principle of equivalence from the axis of selection into the axis of combination (Jakobson 1988: 39). Parallelism always means some kind and extent of equivalence combined with some extent of difference, with a countless number of possible combinations. The basis for distinguishing and describing the types of parallelism could be the distribution of equivalent and different elements across linguistic levels. For example, grammatically parallel units may belong either to different semantic fields or to the same semantic field, depending on the tradition; in some traditions it is required that in the parallel units all the elements have counterparts, other traditions prefer elliptical parallelism, etc. Parallelism is a powerful poetical tool that, with the help of recurrences, is able to draw attention to the similarities between different things or situations, to create links between things that do not belong together in conventional thought and/or language (cf. Frog 2014). This characteristic of parallelism applies diversely in different traditions and genres as well.

\section{PRESENCE OF PARALLELISM IN ESTONIAN FOLKLORE GENRES}

Parallelism finds diverse use in folklore, being one of the main factors signalling the poetic nature of folklore texts and thus securing the correct interpretation of the message. Functions and features of parallelism vary across genres, as 
do the extent of use and regularity. The current chapter aims to give a general overview of the presence of parallelism in Estonian folklore. In the framework of this article parallelism is defined as a recurrence of syntactic structures in contiguous or nearby passages together with some kind of semantic relations. In Estonian folklore parallelism is often elliptical - not all the elements of the main clause have to be repeated in parallel clauses - especially when parallelism occurs within the limits of a sentence or saying. ${ }^{3}$ In addition, as Estonian has free word order, the syntactically parallel units do not have to have the same word order. One can notice, though, that the longer the units, the more exactly parallel units follow the syntax of the main unit, and contain repetition, in order to retain the coherence and give a clear signal of the presence of parallelism (cf. Saarinen 2014: 109). In the long lines of Karelian laments loaded with metaphorical figures, the coherence is secured by a stricter word order together with repetitions (Stepanova 1985; Leino 1974). In several genres of Estonian folklore uses and features of parallelism have been studied more or less thoroughly, whereas on the others it is possible to make only very general remarks.

\section{Songs}

The Estonian folksong tradition can roughly be divided into two broad classes: (1) runosongs - ancient indigenous tradition, shared with other Finnic peoples, featuring a coherent poetical system that includes alliteration and parallelism; (2) rhymed songs - newer tradition (religious as well as secular) adopted from European culture mainly through Germans who inhabited the country as a higher class from the thirteenth until the twentieth century. ${ }^{4}$ In addition to that, there are several groups of so-called transitional songs with a looser poetic form, which hybridly use the elements of both aforementioned classes, as well as other flows of tradition, with each group having its specific features: dance songs, game songs, soldiers' songs, situational village songs, and sentimental ballads. ${ }^{5}$

In runosongs, verse parallelism is considered as one of the main constituents of poetic texture, next to alliteration and specific metre. In addition to the regular presence on verse level, parallelism often structures the composition of larger content blocks. Sometimes multiple layers are embedded into each other, as in the following example where three levels of parallelism are embedded, with verse parallelism occurring at the most basic level. 
(1)

Kuuli poissi laulavetamõtli hundi hulvaveta, soe sorgu laskeveta, mõtsatörri töünävetä. Kuuli neiu laulaveta mõtli käu kukuveta, sisaski siristeveta. (ERlA 4255)

I heard boys singing -

I thought [that] wolves [are] whining, forest hounds howling, savage dogs crying.

I heard girls singing -

I thought [that] cuckoos [are] calling, nightingales twittering.

Although the presence of parallelism is considered as one of the main differences between runosongs and newer, rhymed songs, parallelism still occasionally occurs in the latter.

(2)

Pidin jätma maha

kallist kodumaad

ja pian unustama

kõige kallima.

(Rüütel 2016: 247)

I had to leave

my dear homeland, and I have to forget

my dearest one.

The Estonian rhymed song tradition has remained unstudied by and large, and we do not have any quantitative data on the occurrence and frequency of parallelism in this song corpus. Nevertheless, Ingrid Rüütel's analysis of the occurrence of parallelism in transitional songs (Rüütel 2012: 487-494, 525-531) reveals the directions of development of the use of parallelism in the process of adopting the rhymed song tradition. 
There are two monographic studies written on the parallelism in runosongs. The first one by Wolfgang Steinitz (1934) is based on the songs of the famous Karelian singer Arhippa Perttunen - the most famous classic of runosongs, on whose songs Elias Lönnrot has largely based his epic Kalevala (Lönnrot 1835). Steinitz's work is important in the current context, as this is the most serious attempt for the classification of parallelism occurring in runosongs (on the basis of semantic relations of the parallel units): firstly, he divided the parallelism instances into (1) synonymous - where the content of a line or phrase is repeated, and (2) analogous - where the phrases with similar content are juxtaposed. Although not concerning Estonian tradition per se, Steinitz's classification is considered to be applying to the runosong tradition in general, and has been accepted and adopted into Estonian runosong discourse, and into the study of folkloric parallelism in general. Karl Reichl (1994: 138) admits that the classification is meaningful and applicable for the southern Slavic and Turkic epic poetry as well.

Several runosong researchers have admitted, though, that the classification of the real cases of runosong parallelism according to Steinitz's 'clear-cut division' appears to be problematic; there is a big grey area on the borderline of two classes, where it is hard or impossible to make a decision as to which class the case should belong (see, e.g., Rüütel 2012: 526). Jukka Saarinen in his article on parallelism in Arhippa Perttunen songs states: "Semantic relations between parallel lines are diverse and their limits fuzzy" (Saarinen 2014: 110).

The second thorough study on parallelism is Helle Metslang's unpublished dissertation (1978) on the syntactic aspects of verse parallelism in Estonian runosongs. Metslang clearly confines her research to what she considers as the most central form of parallelism in the runosong - syntactic parallelism that combines verse-length units (including in addition to it a small subgroup of half-verse parallelism) - and leaves aside parallelism of larger units, admitting its recurrent and multilevel presence in runosongs (Metslang 1978: 30-35, 161). She describes the essence of verse parallelism in runosongs as follows:

Parallelism is a constitutive device in Estonian runosongs, which groups successive lines into a complex whole - a group of parallel lines [...] where the content, and, accordingly, the form of a line is partly repeated, partly varied in successive, parallel lines. In this way the integrated whole idea, a poetical image develops. (ibid.: 12)

Metslang's dissertation is based on the syntactic analysis of large text samples, giving us an overview of the syntactic structure of lines belonging to verse parallelism in Estonian runosongs, and offering a solid foundation for a further analysis of runosong parallelism. Her statistical analysis of the syntactic composition of parallel units demonstrates that the main verse of the paral- 
lelistic group usually contains more words, offering grammatically the most complete and most easily understandable version of the idea. There is no direct need to repeat all the words in parallel lines, and the vacant space can be used for poetical reformulation of the content elements; the place that has become free from the ellipsed words can be filled with additional attributes. According to Metslang's statistics on parallel verse pairs (ibid.: 67-76), there are in average 4 grammatical elements in parallel verse pairs, of which 2.8 are present in both verses; 0.85 are disappearing, i.e. are present in the main line only, and 0.35 are appearing, i.e. are present in the parallel line only. Most often (but not necessarily), the disappearing elements perform the function of either the predicate or the subject, and appearing elements the function of the attribute:

(3)

Kaptin kutsus kajutisse, tüirman oma tubadesse.

(ibid.: 71)

Captain invited to the cabin, steersman to his chambers.

(4)

Laulik ollu mu esäke, sõnaseppa mu sõsare.

(ibid.: 73)

Singer was my father, wordsmith my sister.

Thus, there are syntactic regularities in the grammatical parallelism of the runosong - not all the grammatical elements of the main line have to have counterparts in the parallel line, the syntactic continuity is secured by retaining two, or sometimes only one, sentence element, and new attributive elements can be added. There are plenty of examples of retaining only one element in the second or successive lines, and enlarging it with attributes:

(5)

Mis meil viga viisatassa, isa raha raisatassa.

(ERlA 4084)

We don't have anything wrong with dawdling, spending father's money. 
In this case only the verb is retained, with the semantic parallel containing two words (spend money) and an attribute (owner of this money).

(6)

Küll mind pü̈̈dsid Selja sepad

ja ka raudade tagujad.

(ERlA 4635)

Smiths of Selja did want to catch me,

and so did forgers of iron.

In this example, only the word smith has a parallel in the second line, represented by a poetical synonym 'forger of iron', the (unnecessary) conjunctives filling the rest of the vacant space.

In addition to the syntactic features, specific semantic peculiarities apply, sometimes manifesting themselves as contradictions from the viewpoint of the regular language, e.g.:

(7)

Läksin metsä kondimaie

pühapäivä hommikulla, laupäevä lõune’ella, äripäeva õhtatella.

(E 51746/8 (3))

I went to the woods to walk on the morning of a Sunday, on the midday of a Saturday, on the evening of a workday.

Discrepancies reveal themselves in analogous parallelism, where the lines considered to describe one situation appear to be in contradiction to each other in literal interpretation. In the previous example (7) one special event of walking is presented as to be happening in three different spans of time. Jaan Kaplinski and Helle Metslang have explained that the parallel lines in runosongs should be interpreted as disjunctive - the walking may have happened in any of the cases - in contrast to the conjunctive interpretation common to successive sequences in the regular language (Kaplinski 1997; Metslang 1978: 10). The poetic framework establishes specific rules for conveying the meaning, and leads us to interpret parallel lines differently from the regular language.

Different aspects of parallelism in runosongs have been studied by many researchers (see, e.g., Jaago 1998); most of them still focus on the most basic 
level of parallelism, i.e. verse parallelism. As also the statistical estimations of the occurrence of parallelism are usually confined to verse parallelism, it is hard to indicate real coverage of parallelism in runosongs. Although parallelism does not engage all the lines in runosongs, it is clear that verse parallelism is active throughout the whole process of text creation, covering at least half of the lines, usually considerably more, depending mainly on the functional class in question, as well as individual and regional peculiarities of song tradition (see, e.g., Sarv 2002). Optional, but still frequent parallelism of larger content blocks amplifies the presence of parallelism in runosongs even more.

As already mentioned, we do not have any quantitative data on the occurrence of parallelism in rhymed songs, but parallelism is clearly not a constitutive component in this tradition. The presence of parallelism in transitional songs has been summarized by Ingrid Rüütel (2012: 487-494) as follows: there are considerably fewer occurrences of parallelism in transitional songs than in runosongs; where parallelism is used, there is a clear shift towards the use of analogous parallelism in transitional songs as compared to runosongs; in transitional songs the share of parallel groups consisting of two lines has grown at the expense of longer parallel groups. This is explained by the author with the changed socio-cultural situation and with a quest for greater dynamics in reflecting real-world situations, singers' own ideas, and storylines in transitional (as well as in newer) folksongs.

\section{Short forms of folklore}

Parallelism is remarkably visible in the texture of Estonian short forms of folklore - proverbs, sayings, and riddles. The use of parallelism (or syntactic symmetry) in proverbs and sayings has been treated and analysed in a number of Arvo Krikmann's writings, most focally in his series of articles on the relationships of the rhetorical, modal, logical, and syntactic planes in Estonian proverbs (Krikmann 1998). My own study on the structural preconditions for the euphony in short forms of folklore includes, among others, some statistical observations on the frequency of parallelism: among the 14,000 texts present in the database of sayings 7\% contained syntactic repetitions; among the 5,846 proverb type titles with a length of 4-6 words (three most numerous groups) $48 \%$ were parallelistic ${ }^{6}$ (Sarv 2003: 151-154). We have no statistical data on the use of parallelism in riddles, but a rough estimation says parallelism might be even more general in riddles than in proverbs (for texts see Krikmann \& Krikmann 2012). 
A layer of short forms of folklore in Finnic languages is considered to be using the poetic form of runosongs (see, e.g., Leino 1970; Kuusi 1994; PS; Krikmann 1997; etc.). The runosong form is regarded as the 'poetic code' that historically has been widely applied for poetic expression in general by a number of Finnic peoples. In recordings of short forms of folklore, which mostly derive from the past two centuries, texts of this historical layer have been adapting to the cultural and/or linguistic changes. Often it is hard or even impossible to conclude if the specific text is using the runosong form, whereas the texts of short forms of folklore may be too short to reveal the regularities of poetic structure, may be adopted to the colloquial language, and may reveal the features characteristic of runosong poetics, namely syntactic symmetry, euphonic ornaments, and trochaic rhythm, independently of the specific runosong form. Parallelism in these genres is used worldwide, and as such is not specific to Finnic cultures only.

Nevertheless, the use of runosong poetics is evident in many cases, and, in addition to the combined use of alliteration and parallelism, some texts even reveal traces of quantitative metre: oppind mies oluve juoneb, oppimata oksendeleb 'a learned man drinks the beer, an unlearned one vomits' (EV 14756). It is not rare that the same formulaic expressions have been used across different genres; the same lines or parallelistic groups can acquire different functions, can be sung or said, or sometimes guessed. For example, in 1888 folklore collector Paula Jagor wrote down a riddle all ärg, angus sarved 'a grey ox, sharp horns' (a mill; EM 156, H I 2, 32 (6)), and also a song that contains the same line in a more metrical format as a wish of mummers to a good host: sellel kasuvad /... / kiudud ärjad küürus sarved, allid ärjad angus sarved 'this one will have ... striped oxen, crooked horns, grey oxen, sharp horns' (H I 2, 32; Sarv 2003: 146-147; for examples and parallels in abundance see Krikmann 1997: 74-94).

One of the functions of poetic structuring - parallelism together with euphonic means - in proverbs and sayings is to draw attention to the functional difference of the phrase from regular speech, i.e. its generalizing nature, and sometimes figurative meaning, to secure its right interpretation by the addressees, and its memorability. In proverbs, parallelism usually has a clear semantic task - to point out the relations between objects or phenomena, for example differences within a field of activity like in kauple kui juut, maksa kui saks 'bargain as a Jew, pay as a German [landlord]' (EV 3497) or the similarities between different spheres of action, like in söo, mis küps, räägi, mis tõsi 'eat, what is ripe, speak what is true' (EV 11281) (cf. Krikmann 1998; 1975: 89) or the nature of relation, such as cause and effect. This pointing or comparison of two cases usually forms the substance and idea of the proverb, and cannot be considered as a poetical ornament. While the relation between the two cases is meant to be as unexpected as the new information offered by the proverb, 
and the relationship between the two is not always evident, the coherence of parallel units is often additionally secured by an ellipsis, repetition of words in two parallel phrases, recurrent word order, proverbial formulae like whothis; if - then, and also the words or word pairs signalling a clear contrast like but, not, before - after, sweet - bitter, etc. According to Steinitz's classification, the majority of all the instances of parallelism in proverbs can be considered as analogous.

In sayings, which by their nature are more ornamental and less informational than proverbs, the use of parallelism is more playful, often including enumerations, and synonymous reformulations: mul on kolm kavaleeri: Mulla-Madis, Liiva-Annuss ja Tuone-Tuomass 'I have three suitors: Matthias of Mould, Hannus of Sand, and Thomas of Otherworld' (RKM II 201, 295 (51)). The number and choice of items in this kind of lists and reformulations is variative; items can be easily added or omitted (Sarv 1960: 48-50). There are also parallelistic proverbial sayings that are built up on the comparison of two different cases: pealt kui õun, seest kui sibul 'outside as an apple, inside as an onion' (ERA II 254, 447).

In riddles parallelism is most often present in the form of lists that describe different aspects or parts of the object to be guessed, representing analogous parallelism according to Steinitz's classification. These lists have an ambivalent function: on the one hand, they have to provide enough information for guessing, on the other hand, they avoid naming of the object to be guessed. There are different strategies for avoiding direct naming of the object. Sometimes these are just elliptically omitted, like in: õues mäena, toas veena ${ }^{7}$ 'as a hill outside, as a water inside' (snow; EM 2580), but more often the item(s) to be guessed are renamed, either metaphorically (like an animal for a thing in $\ddot{u} k s$ hani, neli nina 'one goose, four noses' - a pillow; EM 2661), using a proper name (Märt mäe külje pääl, üks jalg all 'Martin on the hillside, one leg under him' - a mushroom; EM 657) or a meaningless/onomatopoeic word (ulpus läheb alpusele kosja, suure pika piibuga ja laia kaabuga 'ulpus goes to propose marriage to alpus, with a big long pipe and a large hat' - taking water out of the well; EM 233). As the literal meaning of this kind of poetic pronouns is relatively unimportant in most cases, or gives only some contours or indirect hints of the object to be guessed, these words can be selected quite freely, and in most cases are chosen as alliterating with the more informative part of the riddle; alliteration is a rather regular, still not compulsory feature in Estonian riddles. In addition to alliteration, riddles contain in abundance playful word-structure repetitions with a vague meaning (like ulpus and alpus in the aforementioned example). There are structural differences in these repetitions depending on the placement of words: if they are placed next to or nearby each other, they 
also alliterate with each other, and only the vowel of the first syllable varies: tikker-tekker läheb taeva munedes 'tikker-tekker goes to the heaven, laying eggs' (hop; EM 2202). In case these quasi-words are placed in parallel phrases, the words are composed in such a way as to alliterate with the informative part: pundrik puus, mandrik maas, Hindrik all heinamaal 'pundrik on the tree, mandrik on the ground, Heinrich down on the meadow' (nut, strawberry, and wild angelica; EM 1784). Word structure repetitions with a vague meaning in different variants can be found in approximately $12 \%$ of the whole corpus of Estonian riddles (ca 94,000 texts altogether) (Sarv 2003: 163-164).

The playfulness and obscurity in riddles can be extended even further, when obscure word structure repetitions are combined with the guessing formula, like in muista mutre, mutrest vetru, vedrust kierupäässe, kierupääst munasse, munast maha plaksti 'guess a nut, from nut to spring, from spring to twisthead, from twisthead to egg, from egg down clap' (a gun; EM 1330).

The use of words with an obscure meaning to name the object to be guessed is reportedly common to riddles in various languages and cultures (Hart 1964), and the use of word pairs is not uncommon either (cf. Taylor 1951; the bestknown example in English is probably humpty-dumpty representing an egg); nor is the use of obscure guessing formula, e.g. riddle come, riddle come rarlet, my petticoat's lined with scarlet, etc. (ibid.: 232).

In addition to the parallelism that enumerates different aspects of the object to be guessed, also the synonymous parallelism similar to that of runosongs is sometimes applied, e.g. vee voonake, järve lambake kükitab külatänaval 'sheep of water, lamb of lake is squatting on a village street' (frog; EM 2489).

Compared to the use of parallelism in proverbs, in riddles there are usually more units in the parallel lists, the units of parallelism tend to be shorter, and there are more direct word-repetitions; the most striking difference is the use of obscure and quasi-words that enhance the use of alliteration as well as wordstructure repetitions. Compare, for example, the proverb kui kurõmarja samblõ seeh omma ehk kasussõ, sis aja rügä sisse sügävähe; kui kurõmarja sambla pääl kasussõ, sis tee rügä ägli alla 'when the cranberries are or grow deep in the moss, then you should sow rye deep in the ground; when the cranberries grow on the moss, then you should sow rye straight under the harrow' (EV 4564) vs. mehed Võnnusta tulevad, tükk puud, tükk luud, tükk nahknuustakud, tükk ennast hilbakud, kaks pääd, kaheksa sarve, kaks hända roodulesta, kaks auku mulgulesta 'men are coming from Võnnu, a piece of wood, a piece of bone, a piece of worn leather, and a piece of oneself ragged, two heads, eight horns, two ribbed tails, two holey holes' (oxen in yoke and a man; EM 580). 
In addition to songs and short forms of folklore, parallelism occurs with some frequency also in other genres of folklore. The use of parallelism in charms and children's rhymes is characterized by the hybridity of poetic flows: it may include synonymous parallelism typical of runosongs, comparisons of different situations or circumstances, enumerations, chains, etc. Playfulness and some obscurity in connection with euphonic ornamentation are characteristic of both genres as well: in charms this serves a function similar to riddles, namely to avoid direct naming or the object in question. In narrative genres like fairy tales, legends, and anecdotes either two oppositional situations or gradation with three (or more) situations is expressed parallelistically, adding a poetic effect to the narrative texts (cf. Laugaste 1986: 165).

\section{THE CONCEPT OF POETICAL SYSTEM AS A FRAMEWORK FOR NATURAL TYPOLOGY OF PARALLELISM}

The following attempt to create a typology of parallelism in Estonian folklore proceeds from the concept of poetical system (Sarv 2000), which is defined as a complex of linguistic and poetic features in a specific poetic tradition, forming a coherent whole and present throughout the whole process of text creation. The coherence of the poetical system is established by the persistent mutual relations of its elements. Such elements of the poetical system can be regarded as canonical or structural features in this specific poetic tradition.

In the case of Finnic runosong tradition as well as other poetic genres many researchers have noted that parallelism with its specific semantic structure widens the possibilities for the use of alliteration (see, e.g., Leino 1974: 125; Laugaste 1969: 24; Honko 1963: 103-104; Metslang 1978; Sarv 1999, 2000: 93-95, etc.). The co-dependence of alliteration and parallelism could be statistically proven (Sarv 1999, 2002) by comparing the percentage of alliterative words, which was remarkably higher in the lines belonging to the parallel sequences than in single, so-called orphan lines (cf. also Saarinen 2014). My own hypothesis here has been that not all kinds of parallelism present in runosongs support the use of alliteration, but a specific type of parallelism with persistent relations of alliteration forms a stable element of poetic structure.

My first aim hereby is to find out the main characteristics (linguistic correspondences) for the type of parallelism that supports the use of alliteration in runosongs, and would represent a kind of 'natural type' of parallelism. Subsequently, I will propose two comparable types of parallelism in Estonian poetic folklore, characterized by semantic peculiarities as well as by their relations with euphony. 


\section{STEINITZ'S CLASSIFICATION REVISED}

The classification created by W. Steinitz (1934) divides the cases of parallelism first into synonymous and analogous; the latter class is further divided into antithetic, numerical, variative, chain parallelism, and parallelism of line groups. With his classification, Steinitz gives us an overview of various kinds of parallelism occurring in runosongs; this does not aim, though, to distinguish the structural, canonical type of parallelism. A hint about the essence of canonical parallelism in runosongs can be found in Helle Metslang's conclusion: "The main form of parallelism in Estonian runosong is obviously the syntactic verse parallelism, which confirms semantic analogy" (Metslang 1978: 34). While verse parallelism reigns over the whole process of text creation in runosongs, the parallelism of line groups, chains, and numerical lists occurs only occasionally, and verse parallelism can be embedded into larger groups as in example 1 . Thus, the main form of parallelism in runosongs includes, in Steinitz's terms, the whole class of synonymous parallelism, and part of analogous parallelism.

Another problem with Steinitz's classification is that there is a large grey area between synonymy and analogy (cf. Saarinen 2014: 110). Even the synonyms of colloquial language are not equivalent in all their semantic aspects; in the case of poetical language and line-length units the estimation whether the lines are synonymous or not is much more complicated and subjective. In addition, it has been noted that the unit for the distinction of synonymous/analogous does not have to be a whole line: some of the parallel concepts in parallel lines may be in synonymous relations, some in analogous. In order to have a class for parallel groups including both types of relations, Eduard Laugaste took into use the notion of mixed parallelism (Laugaste 1986: 167).

There is an area where the distinction between synonymous and analogous parallelism is systematically ambivalent. Juhan Peegel noted the relevance of the relation between parallelism and figurative language and brought into use the notion of 'poetical synonym of the runosong' - a word or combination of words with a figurative meaning, which in the parallelism of runosongs is synonymously parallel to a word or combination of words with a regular meaning. ${ }^{8}$ Within the context of a song, the poetical synonym fully covers the semantic field of the main word, and outside of the context of a song it belongs to another semantic field (Peegel 2004). ${ }^{9}$ In the textual practice of the runosong, however, the parallels with a regular meaning are not necessarily obligatory when poetical synonyms are used, in case the latter are well known and do not create problems in understanding as in the following example. 
(8)

Kodu, linnud, tiele, tedred, arule, aned madalad.

(H II 3, 652 (268))

[Let us go] home, birds, set off, grouse, to the field, small geese.

Now, the question arises about how to interpret poetically synonymous words or phrases in the framework of synonymy-analogy distinction. According to Steinitz, birds, grouse, and geese should be interpreted as being analogous as words with a similar content, but not synonymous. In the song, however, the beings going home are not birds but young girls, in the context of the song the birds, grouses, and geese are poetical synonyms of maidens, and as such should be interpreted as synonymous.

Not less complicated is the interpretation of religious beliefs reflected in runosongs. In folk religion spirits often appear in the shape of a bird (see, e.g., Loorits 2000). If in a song there comes sine siiva tsirgokene, vahajalga vaimokene 'a bird with a blue wing, a waxleg[ged] spirit' (H, Wiedemann 2, 262/3 (6)) to talk to a singer, then to estimate if the lines should be considered as synonymous or analogous we should know with whom the singer depicts himself or herself to be speaking; whether the spirit is a poetical synonym for a bird in the singer's worldview, or, on the contrary, the bird represents a spirit, or, for the singer, these two are analogous flying and speaking beings.

In spite of all that, Steinitz's classification has been generally accepted in the runosong discourse, which indicates that analogy and synonymy are still meaningful endpoints in this continuum of semantic relations of parallel lines.

\section{DEFINING CANONICAL RUNOSONG PARALLELISM}

To define canonical parallelism in runosongs, the linguistic correspondences in parallelism with persistent relations of alliteration are to be defined. The syntactic correspondences are described in sufficient detail by Helle Metslang in her dissertation (1978). The following argumentation concerns the semantic correspondences.

As already mentioned, runosong parallelism involves an option for systematic deviations from the regular language. In the cases of analogous parallelism, like in example 7 , in which the singer goes to walk in the woods in three different time spans, contradictions on the literal level appear regularly, and the 
parallel group should be interpreted according to the specific rules established by the poetic framework. According to Kaplinski and Metslang, the parallel units in the runosong are to be interpreted disjunctively; not all the cases presented apply, but just any of the options - the singer goes to the woods either on a Sunday morning, Saturday midday, or workday evening, and the options together form a mental description of a general situation.

My own opinion here is that the group of parallel lines in the runosong is to be decoded conceptwise; in the example cited above, the singer goes to the woods at a time of a day: evening, morning, and midday together form the concept of a time span, and Sunday, workday, and Saturday together form the concept of the day of the week. The list of parallel elements altogether forms a concept of a more abstract level.

I consider as the most distinctive feature of canonical runosong parallelism, almost unnoticed in the previous research, ${ }^{10}$ the equivalence of parallel concepts in the framework of the poetic context. The part of the definition of poetical synonyms by Juhan Peegel (2004), who said that "a poetical synonym fully covers the semantic field of the main word within the context of a song", may be considered as applying to the semantic structure of canonical runosong parallelism in general and as one of its main features. In the context of a parallel group, the parallel words or phrases cover the same semantic field, or more exactly, represent the same general concept, and qua content may be exchanged for one another, be it the synonyms in the regular language, poetical synonyms, the concepts belonging under the same general concept (cohyponyms), or purely poetical word play.

This peculiarity of runosong parallelism can be illustrated with the help of a simple example. In the pair of parallel lines saijõ suvõs sulastõ süvvä, talvõs nä̈̈dsikide närri '[there was enough food] for boys to eat in summer, for maidens to gnaw in wintertime' (H I 2, 595 (1)), the summer and the winter represent times of the year, boys and maidens represent young people (or servants), and eating and gnawing both represent a kind of eating. The whole sentence means something like 'there was enough food for young people to eat throughout the year'. The combination of words into lines is NOT case-specific, i.e. it is not important regarding the meaning of the passage that the boys would eat namely during the winter, and the girls in the summer, or that the boys would namely eat, and the girls would gnaw. The words are combined into lines according to their readiness to alliterate, and their metrical suitability.

With this approach, the distinction of synonymy and analogy of parallel words proves to be irrelevant in terms of understanding; the classification of the semantic relations of the parallel concepts includes different semantic relations (synonymy, cohyponymy, hyperonym with hyponym), poetical figures 
like metaphors, etc. The classification of all the possible relations of the literal meanings of parallel concepts would exceed the limits and aims of the current article. ${ }^{11}$ The presence of parallelism is itself an indicator that the parallel words or phrases should be interpreted as equivalent representatives of a (general) concept. According to Metslang's definition, the main type of parallelism in the runosong confirms semantic analogy: one is expected to be able to detect at least some similarity or intersection in the parallel concepts; the share of difference may vary. In this way even words interpreted as antonyms in the regular language, ${ }^{12}$ such as God and devil, may turn out to be equivalent in a poetical context, e.g. jumal aga aitaks aita panna, saadan salve lükata 'God helps to put [the harvest] to the barn, devil to the storehouse' (EÜS X 191/2 (24)). Brigitte Schulze has noted a similar function of parallelism in Khanti songs, leading to the interpretation of parallel words (e.g. man and woman) as complementary representatives (cohyponyms) of one general concept (hyperonym), rather than as antonyms (Schulze 1987: 134).

The general equivalence of parallel concepts within the framework of a parallel group also allows indefiniteness and haziness of the meaning of parallel words or phrases. More often than not the main line of the parallel group gives us most typical representatives of the general concepts, and the successive lines may quite flexibly use words or poetical figures with a vaguer meaning (Steinitz 1934: 136); it is assumed that these represent the same general concepts and the vagueness of meaning does not bring about any intelligibility problems. For example, in the parallel group kägu meil kukub korjunagi, halli lindu aisa pääl, teder teise veere pä̈al 'a cuckoo is singing on the backrest, a gray bird on a tug, a grouse on another edge' (H II 50, 820 (99)) it may be that the gray bird is a poetical synonym of a cuckoo, but it may easily represent another species of birds. It is not necessary to specify the exact meaning as all the beings in the parallel group are representatives of birds.

The previously described way of forming the meaning, structurally different from that of the regular language, supports the use of alliteration because (a) the parallel word may be placed in any of the parallel lines, and is not related to a specific line; (b) the range of word choice, especially in successive lines, is broader than in the regular language, including all the representatives of the general concept, and allows parallel concepts to be indefinite or vague in meaning (see Sarv 1999; Roper 2012). Thus, in addition to alliteration, parallelism confirming the equivalence of parallel concepts also supports the extensive use of poetical synonyms (representing the general concept figuratively), which form an integral part of the poetical system of runosongs. The parallel word pairs or chains tend to form formulaic units recurrently applied in different environments (see Saarlo 2005; Kolk 1962). The poetic language of runosongs, 
their formulae, and figures have been evolving to fit the poetical system and constraints related to it.

I would propose the definition of canonical runosong parallelism as follows: it is a grammatical verse parallelism where all or some of the syntactic elements of the main verse have corresponding parallels in the successive lines representing the same general notion, and interpreted in the context of parallelism as semantically equivalent, irrespective of their semantic relations in the colloquial language (equivalence, synonymy, metonymy, metaphor, analogy, antonymy, hyponymy, etc.). Because of this semantic equivalence, the parallel words (especially in successive lines) can be selected, combined, and arranged into parallel verses according to their formal features enabling metrical alignment, use of alliteration, and poetical synonyms.

\section{THREE NATURAL TYPES OF PARALLELISM IN ESTONIAN POETIC FOLKLORE}

In more general terms (without restrictions on the verse structure) the type of parallelism, favouring the use of alliteration, could be defined as parallelism of semantic equivalence: in the context of grammatical parallelism, parallel concepts are interpreted as semantically equivalent. In this type of parallelism, parallel concepts are unable to differentiate parallel units as different cases.

The fact that this type of parallelism indeed favours alliteration could be statistically proven with the help of proverbs and sayings. For my study on the structural preconditions for euphony in the short forms of folklore (Sarv 2003) I determined semantic relations of parallel concepts in parallelistic proverbs and sayings in 3,205 texts altogether. The percentage of alliterative words was remarkably higher in the texts with the parallelism instances that included a word pair with equivalent concepts than in the other parallelistic texts; moreover, the average number of alliterative words was even higher in the proverbs and sayings containing two word pairs with semantic equivalence (Sarv 2003), e.g. õigel palju õnnetust, vagal palju viletsust 'fair person has lots of misfortune, pious person has lots of poverty' (EV 14556). This result turned out to be a good proof of the fact that it is meaningful to consider parallelism of equivalent concepts as a distinct (or natural) type of parallelism.

In addition, my investigations revealed that in the case of proverbs and sayings parallelism of equivalent concepts rarely structures the whole text. More often, there were only one or two equivalent word pairs (or longer lists) in grammatically parallel phrases or sentences, and the rest of the parallel word pairs represented case-specific parallelism, e.g.: 
(9)

Ei upsi uus kuub, vaid tantsib täis kõht. (EV 12924)

Not the new coat is hopping, but the full stomach is dancing.

Here the equivalent pair hopping - dancing is combined with parallel nonequivalent word pairs, where the elements are case-specific and not mutually exchangeable: not the new coat - but the full stomach. This regular combination of parallelism of equivalence with case-specific parallelism led me to the assumption that the units of the natural typology of parallelism in Estonian poetic folklore are parallel concepts (words or phrases) in the context of syntactically parallel units, and not the whole parallel groups / parallelistic texts.

In addition to runosongs, where parallelism of semantic equivalence is a canonical and prevailing type of parallelism, this type of parallelism can also be found in transitional songs, charms, children's rhymes, and short forms of folklore.

Case-specific parallelism (or comparative parallelism) could be distinguished as the second natural type of parallelism widely used in different genres of Estonian poetic folklore, the main feature of which, as opposed to the parallelism of semantic equivalence, is that the parallel units represent different, yet at the same time similar or related, cases; the parallel concepts are not mutually exchangeable. Case-specific parallelism is the main type of parallelism used in proverbs and sayings. In my research sample (Sarv 2003) the case-specific word pairs had the alliteration rate approximately similar to that of non-parallelistic proverbs. The use of rhyme was clearly favoured by parallelism, but it was not possible to detect types of semantic relations or type of parallelism that would significantly enhance the use of rhyme.

The main function of parallelism in proverbs and sayings is to draw attention either to the difference of similar cases, or to some kind of similarity or connection of different cases (cf. Krikmann 1998; 1975: 89ff.). In either case the semantic relations of compared parallel concepts are case-specific, i.e. semantically bound to the parallel phrase, and not exchangeable as in parallelism of semantic equivalence. ${ }^{13}$ The difference, similarity or connection is crucial as the main (new) information conveyed by the proverb or saying, its essence, and thus is not as easily interpretable as in the case of parallelism common in runosongs, where the semantic equivalence is highly regular and thus expected. As in the case of parallelism of semantic equivalence, in order for parallelism to be meaningful, the parallel words, phrases or cases have to have something in common.

The use of case-specific parallelism occurs in runosongs mainly in larger blocks like in example 1, where the singing of boys is compared to the voice of 
wolves, but the singing of girls to that of birds. As the parallelism of larger units is only occasional, though frequent, in runosongs, the length of the parallel units is not restricted. The presence of parallelism needs to be made explicit - in this function the formulaic elements (like who - that, when - then, etc.) as well as clear antonyms or synonyms are often used. Also ellipsis, syntactic symmetry, and the repetitions of words serve as signals of the use of parallelism. Casespecific parallelism may also occur as verse parallelism, for example in the form of chains and numbered or gradual lists. Often parallelism of verse pairs includes some case-specific elements.

(10)

Ö̈ jooksis oravikene

härja seljaroodu mööda, päeva lendas pääsokene

härja sarvede vahelta.

(ERlA 10)

Squirrel was running a night

along the backbone of the ox, swallow was flying a day

between the horns of the ox.

In this example running is specific to a squirrel, and flying to a swallow, but the distances and the daytimes can be considered as equivalent.

There are also borderline cases, in which it is hard to decide if the word pairs are equivalent or case-specific, like in a stereotypical parallel group: oh minu ella eidekene ja minu tarka tuadikene, 'oh, my tender mother, and my wise father' (E 17833/4 (18)). One may question if the mothers are typically tender, and fathers typically wise, or whether these words are chosen to represent a positive quality and alliterate with either of the parents.

Parallelism in riddles is usually expressed in the form of case-specific lists: two or more elements, parts or properties of the object to be guessed are one by one characterized, sometimes opposed, like in tuleb kui saks, läheb kui sant 'comes as a rich man, goes as a poor man' (holidays; EM 211). Case-specific parallelism can occasionally be found in transitional songs, rhymed songs, children's songs, and charms. The use of parallelism in narrative folklore is usually case-specific, either with opposing or gradual cases.

Case-specific parallelism may be further divided, for instance, into comparisons (like usually in proverbs and sayings), lists (like mostly in riddles), chains (sometimes in runosongs), negative parallelism (specific repetitive parallelism in runosongs), etc. 
In the structure of riddles the words with obscure meaning have a specific function - to name the object of the riddle without betraying the answer. This leads us to the third type of parallelism, where the semantic peculiarity is related to euphonic ornamentation, namely the word-structure repetitions with obscure meaning - let us call it obscure parallelism. In the parallelism of riddles the semantic function of these word pairs is to be playfully obscure, not to reveal the clear meaning; sometimes the words have onomatopoetic allusions; sometimes the first component in parallel word pairs or chains has a meaning in the regular language, which of course lessens the function of obscurity: hahk nahksepp, must nühksepp, savihaua pühksepp 'grey leathersmith, black scrubsmith, wipesmith of the claygrave' (louse, flea, bedbug; EM 137). In spite of the obscure meaning, in riddles these word pairs are actually there to differentiate the cases, and the slight euphonic difference is enough for that.

The most central area of use for this kind of word pairs is riddles. In the charms the same function of naming something obscurely applies, as the object of the charm is not usually named directly, e.g. metsa uiku, metsa aiku, metsa kuldane kuningas ... 'the uik of woods, the aik of woods, the golden king of woods' from a wolf charm (ERlA 6933) or Hirju hikid, Harju hakid, Läänemaa läbinägijad, Poola punapea tütrukud ... 'hikks from Hirju, hakks from Harju, the prophetic people from western county, redhead girls from Poland ...' in a charm against the unknown sorcerer (ERIA 6859). This kind of word pairs occasionally occur in runosongs as well; these fit seamlessly with the semantic structure of runosong parallelism that allows indefiniteness of meaning. Semantic equivalence or case-specificity does not seem to be a relevant distinction in this type of parallelism: in riddles the rhyming obscure words tend to acquire a case-specific meaning, in the case of runosongs the obscure word pairs, or a meaningful word together with its obscure counterpart, as a rule, can be considered as semantically equivalent. Rhyming structures are not common to the runosong, though; the rhyming structure of the obscure words refers to this specific kind of parallelism, and looking for the potential meaning of such words proves unnecessary, like in the example: tuleb kui kurat koduje, astub kui pärat pesasse 'comes home as a devil, steps into nest as a nevil' (ERIA 6461). The rhyming structure as if refers to the intentional obscurity of the meaning.

\section{CONCLUSIONS}

In various genres of Estonian poetic folklore, grammatical parallelism is a prevalent poetic feature, structuring the formation of poetic text to a considerable extent. Grammatical parallelism in Estonian poetic folklore is often ellipti- 
cal - the parallel iterations do not have to contain all the elements of the main phrase or sentence. Ellipsis makes room for poetic attribution in metered texts, whereas in short forms of folklore its function lies mainly in bringing attention to the cohesion of the parallel units. The word order of parallel units is often variable, as in agglutinative Finnic languages the grammatical endings are there to reveal the functions of words in the sentence.

The types of parallelism can be discerned according to the type of semantic relations between the parallel elements (words or phrases), which is to some extent genre-specific, and related to the euphonic potential of the parallel words. There is a clear tendency: the use of euphony (alliteration and word-structure repetitions) in parallelism increases in relation to the diminishing of the semantic load of the parallel elements.

In the current article three types of parallelism regularly present in Estonian poetic folklore are distinguished:

1) case-specific parallelism, i.e. parallelism that creates a semantic connection between different cases/worlds/images/objects, brings forth the similarity or difference of these cases; meanings of the parallel elements are case-specific (thus semantically not equivalent);

2) parallelism of semantic equivalence, where the parallel elements are mutually exchangeable (not case-specific), and which supports the artistic use of euphony and poetic imagery;

3) obscure parallelism, where the meaning of the words is either totally hidden behind euphony, or is quite irrelevant; the parallel words have a very similar sound structure and alliterate with the nearby words with regular meanings.

All these kinds of parallelism are used in different genres of Estonian poetic folklore and can be used next to each other in instances of grammatical parallelism; at the same time, each of these kinds of parallelism with its semantic functions has, accordingly, a more or less important role in the poetic structure of different genres.

\section{ACKNOWLEDGEMENTS}

This study was supported by the Estonian Ministry of Education and Research (IUT 22-4, "Folklore in the Process of Cultural Communication: Ideologies and Communities"), and by the European Union through the European Regional Development Fund (Centre of Excellence in Estonian Studies). 


\section{NOTES}

1 The systematic actions since 1888 to collect runosongs all over Estonia have resulted in the voluminous collections stored at the Estonian Folklore Archives. The number of recorded song texts is estimated to be ca 150,000, and the corpus (currently in progress) is available via Estonian Runic Songs' Database (http://www.folklore.ee/ regilaul/andmebaas/).

2 Porthan (1766-1788: 22) refers (through the dissertation of Daniel Juslenius) to the writing of Joh. de Champs, which can be found in volume XIII, p. 268, of the opus Diar(ium) Britann(icum).

${ }^{3}$ Ellipsis is not common to all the oral traditions using parallelism; for example, according to R. Austerlitz (1958: 46), in the folksongs of Ob-Ugric peoples usually no more than two elements change in otherwise repetitive long lines. In the parallelism of Turkic and Mongolic folklore, word (or word-stem) repetition has fulfilled an important role (Zhirmunskiy 1974: 660; Harvilahti 1987: 31).

4 For a more extended comparison of the two layers of tradition see Sarv 2009.

5 Transitional songs have been thoroughly studied by Ingrid Rüütel in her monograph, Eesti uuema rahvalaulu kujunemine (The Formation of the Rhymed Estonian Folksong) (2012 [1969]).

6 The share of the parallelistic proverbs in the total archival corpus of Estonian proverbs can probably be estimated as somewhat lower.

7 All the Estonian riddle examples cited can be found according to the type number in the academic publication of Estonian riddles (EM) as well as in the corresponding database (Krikmann \& Krikmann 2012).

8 Poetic synonyms form a basic phenomenon in oral poetic registers generally (cf. Frog 2015: 86-87).

9 The main outcome of Peegel's research on this subject is his dictionary of the poetic synonyms of Estonian runosongs, which contains over 4,000 different synonyms for 462 base words (Peegel 2004).

${ }^{10}$ As far as I know, the only researcher who has introduced the equivalence of parallel words or phrases as a distinctive feature of the runosong was a German researcher Ewald Lang, who called the semantic relation between parallel words or phrases lexical quasisynonymy (Lang 1987: 16-17).

${ }^{11}$ Kanni Labi (Labi \& Sarv 2009) has detected nine classes of semantic relations on the basis of the dictionary of poetical synonyms (Peegel 2004).

${ }^{12}$ One should keep in mind here that even in regular speech antonyms have to have something in common, have to belong to the same category of concepts in order to be interpreted as antonyms. This very same category may easily form an (implicit) hyperonym or a general concept for the antonyms in runosong parallelism.

${ }^{13}$ For securing the coherence of parallel units also repetitions and equivalent concepts may be included. 


\section{ARCHIVAL SOURCES}

\section{Estonian Folklore Archives at the Estonian Literary Museum}

E - manuscript collection of Matthias Johann Eisen

ERA - manuscript collection of the Estonian Folklore Archives

$\mathrm{H}$ - manuscript collection of Jakob Hurt

RKM - manuscript collection of the Estonian State Literary Museum

\section{REFERENCES}

Austerlitz, Robert P. 1958. Ob-Ugric Metrics: The Metrical Structure of Ostyak and Vogul Folk Poetry. FF Communications 174. Helsinki: Suomalainen Tiedeakatemia.

$\mathrm{EM}=$ Eesti mõistatused I-II. 2001-2002. [Estonian Riddles.] Comp. by A. Hussar \& A. Krikmann \& R. Saukas \& P. Voolaid. Ed. by A. Krikmann \& R. Saukas. Tartu: Eesti Keele Sihtasutus.

ERlA = Eesti rahvalaulud: Antoloogia. 1969-1974. [Estonian Folk Songs: Anthology.] Edited by Ülo Tedre. Tallinn: Eesti Raamat. Available at http://haldjas.folklore. ee/laulud/erla/, last accessed on March 8, 2017.

$\mathrm{EV}=$ Eesti vanasõnad I-V:2. 1980-1988. [Estonian Proverbs.] Comp. by A. Hussar \& A. Krikmann \& E. Normann \& V. Pino \& I. Sarv \& R. Saukas. Ed. by A. Krikmann \& I. Sarv. Tallinn: Eesti Raamat.

Fox, James J. 2014. Explorations in Semantic Parallelism. Canberra: ANU Press. Available at http://press.anu.edu.au/publications/explorations-semantic-parallelism, last accessed on March 8, 2017.

Frog 2014. Parallelism, Mode, Medium and Orders of Representation. In: Frog (ed.) Parallelism in Verbal Art and Performance: Pre-Print Papers of the SeminarWorkshop, 26th-27th May 2014. Folkloristiikan toimite 21. Helsinki: Folklore Studies, University of Helsinki, pp. 185-207. Available at https://www.academia. edu/7029240/Parallelism_Mode_Medium_and_Orders_of_Representation, last accessed on March 8, 2017.

Frog 2015. Registers of Oral Poetry. In: Asif Agha \& Frog (eds.) Registers of Communication. Studia Fennica Linguistica 18. Helsinki: Finnish Literature Society, pp. 77-104.

Hart, Donn V. 1964. Riddles in Filipino Folklore: An Anthropological Analysis. Syracuse: Syracuse University Press.

Harvilahti, Lauri 1987. Zwei Fliegen mit einer Klappe: Zum Parallelismus der Sprichwörter. Finnisch-Ugrische Forschungen, Vol. 48, No. 1, pp. 27-38.

Honko, Lauri 1963. Itkuvirsirunous. [Lament Poetry.] In: Matti Kuusi (ed.) Suomen kirjallisuus I: Kirjoittamaton kirjallisuus. Helsinki: SKS \& Otava, pp. 81-128. Available at http://kansanrunous.net84.net/Suomen_kirjallisuus_I/index.htm, last accessed on March 8, 2017.

Jaago, Tiiu 1998. Parallelism. [Parallelism.] In: Tiiu Jaago (ed.) Regilaulu poeetika: Rahvaluule ülemastme kursus regilaulu uurimise meetoditest. Tartu: Tartu Ülikool. 
Available at http://www.folklore.ee/UTfolkl/loengud/poeetika/3parallelism.html, last accessed on March 8, 2017.

Jakobson, Roman \& Pomorska, Krystyna 1983 [1980]. Parallelism. In: Roman Jakobson \& Krystyna Pomorska. Dialogues. Cambridge, Mass.: MIT Press, pp. 99-109.

Jakobson, Roman 1987. Grammatical Parallelism and Its Russian Facet. In: K. Pomorska \& S. Rudy (ed.) Language in Literature. Cambridge, Mass. \& London: Harvard University Press, pp. 145-179.

Jakobson, Roman 1988. Linguistics and Poetics: The Metaphoric and Metonymic Poles. In: D. Lodge (ed.) Modern Criticism and Theory: A Reader. London \& New York: Longman, pp. 32-61.

Kaplinski, Jaan 1997 [1972]. Parallelismist lingvisti pilguga. [About Parallelism through the Eyes of a Linguist.] In: Võimaluste võimalikkus. Tallinn: Vagabund, pp. 205230.

Kolk, Udo 1962. Värsisisesed vormelid eesti regivärsilises rahvalaulus. [Small-Scale Formulae in the Lines of Estonian Runosongs.] Töid filoloogia alalt I. Tartu Riikliku Ülikooli toimetised 117. Tartu: Tartu Riiklik Ülikool, pp. 71-153.

Krikmann, Arvo 1975. Vanasõnade sisu ja maailmavaate uurimise problemaatikast. [On the Problems of Studying the Content and Worldview of Proverbs.] Diss. (PhD Thesis). Institute of Language and Literature at the Academy of Sciences of the Estonian SSR. Unpublished.

Krikmann, Arvo 1997. Sissevaateid folkloori lühivormidesse I. [Insights into Short Forms of Folklore.] Tartu: Tartu Ülikooli Kirjastus. Available at http://haldjas.folklore. ee/ kriku/LEX/KATUS.HTM, last accessed on March 8, 2017.

Krikmann, Arvo 1998. On the Relationships of the Rhetorical, Modal, Logical, and Syntactic Planes in Estonian Proverbs. Folklore: Electronic Journal of Folklore, Vol. 6, pp. 99-127, DOI: 10.7592/FEJF1998.06.synt; Vol. 8, pp. 51-99, DOI:10.7592/ FEJF1998.08.syntmod2; Vol. 9, pp. 71-96, DOI:10.7592/FEJF1998.08.syntmod3.

Krikmann, Jaak \& Krikmann, Arvo 2012. Eesti mõistatused. [Estonian Riddles.] Database. Tartu: Estonian Literary Museum. Available at http://folklore.ee/ moistatused/, last accessed on March 8, 2017.

Küper, Christoph 1988. Sprache und Metrum: Semiotik und Linguistik des Verses. Tübingen: Max Niemeyer Verlag.

Kuusi, Matti 1994 [1978]. Questions of Kalevala Metre. In: Anna-Leena Siikala \& Sinikka Vakimo (eds.) Songs beyond the Kalevala: Transformations of Oral Poetry. Studia Fennica Folkloristica 2. Helsinki: Suomalaisen Kirjallisuuden Seura, pp. 41-55.

Labi, Kanni \& Sarv, Mari 2009. Regilaul through the Looking-Glass: Remarks on the Figurative Language. In: Liisa Vesik \& Nikolay Kuznetsov (eds.) International Academic Interdisciplinary Conference "From Language to Mind 3": On the Occasion of the 70th Birthday of Academician Arvo Krikmann. Abstracts. Tartu: ELM Scholarly Press, p. 23. Available at http://www.digar.ee/arhiiv/et/ perioodika/14214, last accessed on March 8, 2017.

Lang, Ewald 1987. Parallelismus als universelles Prinzip sekundärer Strukturbildung. In: Ewald Lang \& Gert Sauer (eds.) Parallelismus und Etymologie: Studien zu Ehren von Wolfgang Steinitz anläßlich seines 80. Geburtstags am 28. Februar 1985. Vol. I. Berlin: Akademie der Wissenschaften der DDR, pp. 1-54. 
Laugaste, Eduard 1969. Sõnaalguline ja sisealliteratsioon eesti rahvalauludes. [WordInitial and In-Word Alliteration in Estonian Folk Songs.] Eesti rahvalaulu struktuur ja kujundid I. Tartu Riikliku Ülikooli toimetised 234. Tartu: Tartu Riiklik Ülikool, pp. 3-356.

Laugaste, Eduard 1986. Eesti rahvaluule. [Estonian Folklore.] Tallinn: Valgus.

Leino, Pentti 1970. Strukturaalinen alkusointu suomessa. [Structural Alliteration in Finnish.] Suomalaisen Kirjallisuuden Seuran toimituksia 298. Helsinki: Suomalaisen Kirjallisuuden Seura.

Leino, Pentti 1974. The Language of Laments: The Role of Phonological and Semantic Features in Word Choice. Studia Fennica, Vol. 17, pp. 92-131.

Lönnrot, Elias 1835. Kalewala taikka Wanhoja Karjalan runoja Suomen kansan muinosista ajoista. [The Kalevala, or Old Karelian Poems about Ancient Times of the Finnish People.] Helsinki: Suomalaisen Kirjallisuuden Seura. Available at http:// www.doria.fi/handle/10024/59003, last accessed on March 8, 2017.

Loorits, Oskar 2000 [1938]. Lind - eesti omakultuuri ja vaimsuse vapp. [Bird - Emblem of Estonian Indigenous Culture and Spirituality.] In: Meie, eestlased. [We Estonians.] Tartu: Ilmamaa, pp. 182-207.

Metslang, Helle 1978. Süntaktilisi aspekte eesti regilaulu värsiparallelismis. [Syntactic Aspects in Verse Parallelism of Estonian Runosongs.] Diss. (PhD Thesis). University of Tartu. Manuscript at the Estonian Folklore Archives.

O’Connor, Michael Patrick 1993. Parallelism. In: Alex Preminger \& T. V. F. Brogan (eds.) The New Princeton Encyclopedia of Poetry and Poetics. Princeton, New Jersey: Princeton University Press, pp. 877-879.

Peegel, Juhan 2004. Nimisõna poeetilised sünonüümid eesti regivärssides. Teine, läbi vaadatud ja ühtlustatud trükk. [Poetical Synonyms of Substantives in Estonian Runo Verses.] Tallinn: Eesti Keele Sihtasutus.

Porthan, Henricus Gabriel 1766-1778. De Poesi Fennica. Åbo: Frenckell. Available at https://ia801307.us.archive.org/32/items/PorthanDePoesiFennica5Pts176688/ Porthan-DePoesiFennica5Pts-1766-88.pdf, last accessed on March 1, 2017.

Porthan, Henrik Gabriel 1983 [1766-1778]. Suomalaisesta runoudesta: Kääntänyt ja johdannon kirjoittanut Iiro Kajanto. [About Finnish Poetry: Translated and with a Preface by Iiro Kajanto.] Suomalaisen Kirjallisuuden Seuran toimituksia 389. Vaasa: SKS.

PS = Proverbia septentrionalia: 900 Balto-Finnic Proverb Types with Russian, Baltic, German and Scandinavian Parallels. 1985. By Matti Kuusi in cooperation with Marje Joalaid \& Arvo Krikmann \& Pentti Leino \& Elsa Kokare \& Kari Laukkanen \& Vaina Mälk \& Ingrid Sarv. FF Communications 236. Helsinki: Suomalainen Tiedeakatemia.

PT $=$ Perinteentutkimuksen terminologia . [Folkloristic Terminology.] 1998. Edited by Satu Apo \& Eeva-Liisa Kinnunen. Helsinki: Helsingin Yliopiston kulttuurien tutkimuksen laitos.

Reichl, Karl 1994. Parallelism in South Slav and Turkic Epic Poetry: Towards a Poetics of Formulaic Diction. In: M. Branch \& C. Hawkesworth (eds.) The Uses of Tradition: A Comparative Enquiry into the Nature, Uses and Functions of Oral Poetry in the Balkans, the Baltic, and Africa. London: School of Slavonic and East European Studies, University of London, pp. 135-150. 
Roper, Jonathan 2012. Synonymy and Rank in Alliterative Poetry. Sign Systems Studies, Vol. 40, Nos. 1/2, pp. 82-93.

Rüütel, Ingrid 2012. Eesti uuema rahvalaulu kujunemine. [The Formation of the Rhymed Estonian Folk Song.] Tartu: Eesti Kirjandusmuuseumi Teaduskirjastus.

Rüütel, Ingrid 2016. Muhumaa laule ja lugusid: Mis on jäänud jälgedesse II. [Songs and Tales of Muhu Island.] Tartu: Eesti Kirjandusmuuseumi Teaduskirjastus.

Saarinen, Jukka 2014. "Said a Word, Uttered Thus": Structures and Functions of Parallelism in Arhippa Perttunen's Poems. In: Frog (ed.) Parallelism in Verbal Art and Performance: Pre-Print Papers of the Seminar-Workshop, 26th-27th May 2014. Folkloristiikan toimite 21. Helsinki: Folklore Studies, University of Helsinki, pp. 106-119.

Saarlo, Liina 2005. Eesti regilaulude stereotüüpiast: Teooria, meetod ja tähendus. [On the Stereotypy of Estonian Runosongs: Theory, Method, and Meaning.] Dissertationes folkloristicae Universitatis Tartuensis 5. Tartu: Tartu Ülikooli Kirjastus. Available at http://dspace.ut.ee/bitstream/handle/10062/838/saarlo.pdf?sequence $=5$, last accessed on March 8, 2017.

Sarv, Ingrid 1960. Rahvapärane võrdlus kui kõnekäänu eriliik. [Folk Comparisons as a Special Kind of Sayings.] Tartu Riikliku Ülikooli toimetised 94. Tartu: Tartu Riiklik Ülikool.

Sarv, Mari 1999. Regilaul: Clearing the Alliterative Haze. Folklore: Electronic Journal of Folklore, Vol. 10, pp. 126-140. DOI: 10.7592.FEJF1999.10.alliter.

Sarv, Mari 2000. Regilaul kui poeetiline süsteem. [Runosong as a Poetic System.] In: J. Oras \& E.-H. Västrik (eds.) Paar sammukest XVII. Eesti Kirjandusmuuseumi aastaraamat. Tartu: Eesti Kirjandusmuuseumi Teaduskirjastus, pp. 7-122.

Sarv, Mari 2001. Parallelismi liigitamise poole. [Towards Classifying Parallelism.] In: M. Hiiemäe \& K. Labi (eds.) Klaasmäel. Pro Folkloristica VIII. Tartu: Eesti Kirjandusmuuseum, pp. 175-185.

Sarv, Mari 2002. Regilaulu värsitunnuste kihelkonnasisene varieeruvus (Haljala). [The Variativity of Poetic Features of Verse Lines of Regilaul within a Parish (Haljala).] In: M. Hiiemäe \& K. Labi \& J. Oras (eds.) Lemmeleht. Pro Folkloristica IX.Tartu: Eesti Kirjandusmuuseum, pp. 215-230. Available at http://www.folklore.ee/era/ nt/PF9/index.html, last accessed on March 8, 2017.

Sarv, Mari 2003. Lühivormide heakõlalisuse ehituslikest eeldustest. [On the Structural Preconditions for the Euphony in Short Forms of Folklore.] In: A. Krikmann (ed.) Uurimusi folkloori lühivormidest. Reetor 1. Tartu: Eesti Kirjandusmuuseum, pp. $145-172$.

Sarv, Mari 2009. Stichic and Stanzaic Poetic Form in Estonian Tradition and in Europe. Traditiones, Vol. 38, No. 1, pp. 161-171. Available at https://ojs.zrc-sazu.si/ traditiones/article/view/1059/839, last accessed on March 8, 2017.

Sarv, Mari 2015. Veel kord regilaulu parallelismist, poeetilisest sünonüümiast ja analoogiast. [Once More on the Parallelism of Runosong, on the Poetical Synonymy and Analogy.] Methis: Studia humaniora Estonica, No. 16, pp. 27-34. http:// dx.doi.org/10.7592/methis.v13i16.12451.

Schulze, Brigitte 1987. Zum Wortparallelismus in der (nord-)ostjakischen Volksdichtung. In: E. Lang \& G. Sauer (eds.) Parallelismus und Etymologie: Studien zu Ehren von Wolfgang Steinitz anläßlich seines 80. Geburtstags am 28. Februar 1985, II. Berlin: Akademie der Wissenschaften der DDR, pp. 111-146. 
Steinitz, Wolfgang 1934. Der Parallelismus in der finnisch-karelischen Volksdichtung. FF Communications 115. Helsinki: Suomalainen Tiedeakatemia.

Stepanova, Aleksandra 1985. Metaforicheskii mir karel'skikh prichitanii. [Metaphorical World of Karelian Lamentations.] Leningrad: Nauka.

Taylor, Archer 1951. English Riddles from Oral Tradition. Berkeley \& Los Angeles: University of California Press.

Zhirmunskiy 1974 = Zhirmunskii, Viktor. O tiurkskom narodnom stikhe. [About Turkish Folk Poem.] In: Tiurkskii geroicheskii epos. Leningrad: Nauka, pp. 644-680.

\section{INTERNET SOURCES}

Estonian Runic Songs' Database. Available at http://www.folklore.ee/regilaul/andmebaas/, last accessed on March 8, 2017.

Mari Sarv has worked at the Estonian Folklore Archives of the Estonian Literary Museum, Estonia, since 1996. Since 2012 head of the research group of the Estonian Folklore Archives.

mari@folklore.ee 